\title{
Sensitive system for visualising biotinylated DNA probes hybridised in situ: rapid sex determination of intact cells
}

\author{
J BURNS, VTW CHAN, JA JONASSON, $†$ KA FLEMING, SUSAN TAYLOR, \\ J O'D MCGEE*
}

From the *University of Oxford, Nuffield Department of Pathology, John Radcliffe Hospital, Oxford and the †Department of Medical Genetics, Churchill Hospital, Oxford

SUMMARY A fast and sensitive method for detecting biotinylated deoxyribonucleic acid (DNA) probes was used for sex determination of cells and tissues by in situ hybridisation of a probe "specific" for the Y chromosome (pHY2.1). Within 24 hours this procedure visualises the Y chromosome in fetal and adult cells and tissue, without background noise. This procedure should facilitate antenatal determination of sex on small numbers of uncultured cells. The sensitivity of the procedure also permits the chromosomal assignment of genes present in low copy number.

The molecular pathophysiology of some inherited ${ }^{1}$ and acquired ${ }^{2}$ diseases can now be described in terms of abnormalities or inappropriate transcription of DNA, or both. To integrate these homogenate data ${ }^{2}$ with the cellular concepts of disease identification of cells in intact tissue that contain and express one or more specific genes is required. Sequences of nucleic acid can be shown in cells by in situ hybridisation. Radiolabelled probes give high sensitivity. These probes, however, have limitations for the microscopic visualisation of genes and their transcripts in tissues - for example, relatively poor microscopic resolution, background noise, incompatibility with other histochemical procedures, and the need for autoradiography, which is time consuming. Some of these limitations are obviated by biotinylated probes, ${ }^{34}$ but the systems for visualising these in situ are less sensitive. ${ }^{56}$

As we were interested in detecting rare gene and messenger ribonucleic acid species in intact cells we set out to increase the sensitivity of the detection of biotinylated DNA probes hybridised in situ. For three reasons, we chose to work with a DNA probe "specific" for Y chromosomes (pHY2.1), which labels repetitive sequences on the $\mathrm{Y}$ chromosome. Firstly, there are about 2100-2200 copies of pHY2. 1 in the human male genome; 2000 of these are on the $\mathrm{Y}$ chromosome and should, theoretically, be easily visualised. Secondly, the 100-200 other

Accepted for publication 23 April 19x: copies (also present in the female genome) are distributed over other chromosomes ${ }^{7}$ : visualisation of these would give a rough estimate of sensitivity. Thirdly, sexing of fetal and adult cells is relevant to the detection of several disorders in man.

In this paper a quick procedure for detection is described, which visualises biotinylated $\mathrm{pHY} 2 \cdot 1$ in situ on the $\mathrm{Y}$ chromosome in cells and tissue and is also sensitive enough to detect the rarer autosomal copies. Sex determination can be carried out on intact fetal cells (free and cultured amniotic cells, chorionic villous biopsies) and adult cells (peripheral white blood cells, sperm, solid tissues) within 24 hours. This procedure should facilitate an accelerated antenatal diagnosis of sex and can also be used for the chromosomal location of genes.

\section{Materials and methods}

PREPARATION OF CELLS AND TISSUES

Lymphocyte cultures for analysis of interphase and metaphase cells were set up by adding $0.4 \mathrm{ml}$ of heparinised venous blood to $5 \mathrm{ml}$ of HEPES buffered Eagle's minimal essential medium supplemented by $20 \%(\mathrm{v} / \mathrm{v})$ inactivated human serum, antibiotics, and phytohaemagglutinin. After 72 hours at $37^{\circ} \mathrm{C}$ the cells were either treated with 0.05 $\mu \mathrm{g} / \mathrm{ml}$ colcemid for 45 minutes and harvested or deoxybromouridine was added to a concentration of $200 \mu \mathrm{g} / \mathrm{ml}$ and incubation continued for a further 16 hours. The cells were washed, resuspended in fresh medium containing $0.25 \mu \mathrm{g} / \mathrm{ml}$ thymidine, and incu- 
bated for six hours; colcemid $(0.05 \mu \mathrm{g} / \mathrm{ml})$ was added during the last 45 minutes of the incubation. The cells were centrifuged, resuspended for five minutes at $37^{\circ} \mathrm{C}$ in hypotonic $(0.08 \mathrm{~mol} / \mathrm{l})$ potassium chloride, centrifuged, and fixed in methanol/acetic acid $(3: 1 \mathrm{v} / \mathrm{v})$ for at least 30 minutes. Air dried preparations were made on regular microscopic glass slides or multiwell glass slides (C H Henley, Essex, United Kingdom) and stored at $-70^{\circ} \mathrm{C}$. Multiwell slides have four wells (12 $\mathrm{mm}$ diameter) separated by plastic. Cells or sections of tissue mounted on these slides enable four separate probes to be hybridised simultaneously on replicate samples under identical conditions.

Routine cytogenetic preparations of white blood cells from phenotypically and karyotypically normal adult men and women were used in a double blind study to determine each patient's sex by in situ hybridisation. These samples were stored at room temperature for less than one year.

Peripheral blood lymphocytes were separated from whole blood by separation through FicollHypaque (Pharmacia, Sweden). White blood cells were cytospun on to regular glass slides, fixed in Carnoy's fluid (ethanol: chloroform: glacial acetic acid $=6: 3: 1$ ) for 10 minutes, and stored at room temperature for one to two days.

Cells taken directly from $1 \mathrm{ml}$ of amniotic fluid (16-21 weeks' gestation) were fixed in methanol/ acetic acid for $\mathbf{3 0}$ minutes, applied to regular glass microscopic slides, air dried, and stored at room temperature for several days. Cells from $10-20 \mathrm{ml}$ amniotic fluid were cultured in plastic tissue culture flasks in HEPES buffered Eagle's minimum essential medium with Hanks's salts supplemented with $20 \%(\mathrm{v} / \mathrm{v})$ fetal calf serum and antibiotics. After 10-14 days' incubation the cells were treated with $0.05 \mu \mathrm{g} / \mathrm{ml}$ of colcemid for 45 minutes and harvested by trypsination. Chromosome spreads were made in the same way as for lymphocyte cultures (see above) and stored at room temperature for several months.

Chorionic villi (5-10 $\mathrm{mg}$ ) aspirated at six to 10 weeks from the last menstrual period were collected at room temperature in HEPES buffered Eagle's minimum essential medium containing heparin. In vitro cultures were prepared in Chang medium and incubated overnight at $37^{\circ} \mathrm{C}$. Colcemid was added $(0.05 \mu \mathrm{g} / \mathrm{ml})$ and incubation continued for 45 minutes. The villi were transferred to $3.5 \mathrm{mmol} / \mathrm{l}$ sodium citrate for five minutes and fixed in methanol/acetic acid for at least 15 minutes; the fixative was decanted and the cells placed in $60 \%$ $(v / v)$ acetic acid in water for two minutes. The suspension was transferred to methanol/acetic acid, air dried on regular glass slides, and stored at room temperature for several weeks.

Buccal smears and sperms from normal fertile donors were prepared ${ }^{8}$ and stored at room temperature for up to one week. Buccal smears were fixed for one hour at room temperature in ethanol:ether $(1: 1 \mathrm{v} / \mathrm{v})$. Sperm were treated with hypotonic potassium chloride and fixed as for lymphocyte cultures (see above).

Fresh human tissue was collected immediately after elective surgical resection, frozen rapidly, and stored in liquid nitrogen. Sections of cryostat tissue (6 $\mu \mathrm{m}$ thick) were mounted on multiwell slides coated with polylysine, fixed in Carnoy's fluid at room temperature for $\mathbf{1 0}$ minutes, washed twice in ethanol (10 minutes), air dried, and stored at $-70^{\circ} \mathrm{C}$.

IN SITU HYBRIDISATION AND BIOTINYLATED PROBE DETECTION

The Y "specific" probe pHY2.1 and pBR322 were labelled with dUTP-biotin by nick translation according to the manufacturer's instructions (Enzo Biochemicals, New York). The degree of dUTPbiotin substitution in different translations was 15$40 \%$ and $30-40 \%$ for pHY2. 1 and pBR322, respectively. The labelled probes $(20 \mu \mathrm{g} \mathrm{DNA} / \mathrm{ml})$ werê stored in $5 \mu \mathrm{l}$ aliquots at $-70^{\circ} \mathrm{C}$ in $1 \mathrm{mmol}$ ethylene diamino tetra-acetic acid (EDTA), mmol/l Tris hydrochloric acid, $\mathrm{pH} 7 \cdot 3$.

Before hybridisation sections of tissue, sperm, and buccal smears were incubated sequentially at $22^{\circ} \mathrm{C}$ for 30 minutes in methanol containing $3.3 \%(\mathrm{v} / \mathrm{v})$ hydrogen peroxide, ethanol (10 minutes), xylene (10 minutes), ethanol (10 minutes) and air dried. For all other cell targets (chorionic villi, white blood cells, etc.) incubation in methanol and hydrogen peroxide was omitted. Hybridisation buffer $(10 \mu \mathrm{l})$ containing $0 \cdot 2-2.0 \mathrm{ng}$ biotinylated $\mathrm{pHY} 2 \cdot 1$ or pBR322 (as a control) was pipetted on to each well 3 or regular glass slide and covered with a circular (14 $\delta$ mm diameter) glass cover slip. The cover slips on cells and tissue mounted on multiwell slides were $\mathrm{O}$ not sealed; cover slips on regular glass slides were sealed with rubber solution. Hybridisation buffer contained $50 \%(\mathrm{v} / \mathrm{v})$ formamide (Sigma UK), $10 \%$ $(\mathrm{v} / \mathrm{v})$ dextran sulphate (BDH UK), $2 \times \mathrm{SSC}, 0.1 \mathrm{G}$ mmol/l EDTA and $0.05 \mathrm{mmol} / \mathrm{l}$ Tris hydrochloric $N$ acid, $\mathrm{pH} 7.3 ; 1 \times \mathrm{SSC}=0.15 \mathrm{~mol} / \mathrm{l}$ sodium chloride, $0.015 \mathrm{~mol} / \mathrm{l}$ sodium citrate.

As a further control cells and tissue were incubated under similar conditions with hybridisation $\stackrel{\bullet}{=}$ buffer only. Slides were placed in sealed plastic con- $\stackrel{\oplus}{\rightarrow}$ tainers containing enough water to saturate the 0 atmosphere. The cells or tissue and probe (in hybridisation buffer) were denatured simultaneously in a $\mathbb{D}$ hot air oven at $73^{\circ} \mathrm{C}$ for six minutes. Containers 
were transferred to $42^{\circ} \mathrm{C}$ and hybridised for 16 hours. Slides were washed sequentially in $2 \times$ SSC at $22^{\circ} \mathrm{C}$ for 30 minutes and in $0.1 \times S S C$ at $42^{\circ} \mathrm{C}$ for 30 minutes; then in $2 \times$ SSC for 15 minutes, and PBT [0.15 mol $/ 1$ sodium chloride, $0.01 \mathrm{~mol} / 1$ phosphate buffer, $\mathrm{pH} 7 \cdot 4,5 \%$ bovine serum albumin $(\mathrm{v} / \mathrm{v})$, $0.1 \%$ Triton $\mathrm{X}-100(\mathrm{v} / \mathrm{v})]$ for 15 minutes at $22^{\circ} \mathrm{C}$.

Biotinylated probes were detected directly by biotinylated streptavidin peroxidase conjugate or indirectly by polyclonal goat or rabbit antibiotin IgG (Enzo Biochemicals, New York), followed by peroxidase labelled rabbit antigoat immunoglobulin or swine antirabbit Ig, respectively (Dakopatts, Denmark). For detection of the probe using streptavidin, PBT was decanted and slides incubated at $37^{\circ} \mathrm{C}$ for 60 minutes in biotinylated streptavidin peroxidase (diluted 1:200 in PBT). Slides were washed twice at $22^{\circ} \mathrm{C}$ for 15 minutes in PBST $(0 \cdot 15$ mol/l sodium chloride, $0.1 \%(\mathrm{v} / \mathrm{v})$ Tween $20,0.01$ mol/l phosphate buffer, $\mathrm{pH} \mathrm{7.4)}$ in phosphate buffered saline $(0.15 \mathrm{~mol} / \mathrm{l}$ sodium chloride, containing $0.01 \mathrm{~mol} / \mathrm{l}$ phosphate buffer, $\mathrm{pH} \mathrm{7.4)}$ for five minutes, and reacted for four minutes at $22^{\circ} \mathrm{C}$ with $0.5 \mathrm{mg} / \mathrm{ml}$ diaminobenzidine hydrochloric acid (DAB) (Polysciences, New York) in phosphate buffered saline containing $0.0012 \%$ (v/v) hydrogen peroxide. Slides were washed in distilled water and the $\mathrm{DAB} /$ hydrogen peroxide signal amplified by silver precipitation (see below).

For antibody detection of the biotinylated probe PBT was decanted and slides incubated at $37^{\circ} \mathrm{C}$ for 60 minutes in goat (diluted 1:500 in PBT) or rabbit (diluted 1:200 in PBT) antibiotin IgG. Slides were washed in PBT at $22^{\circ} \mathrm{C}$ for 15 minutes and incubated at $37^{\circ} \mathrm{C}$ for 60 minutes in peroxidase labelled rabbit antigoat IgG (diluted 1:50 in PBT) or swine antirabbit IgG (diluted 1:20 in PBT). Slides were washed in PBST and phosphate buffered saline and incubated in the $\mathrm{DAB} /$ hydrogen peroxide substrate for four minutes (see above).

The DAB/hydrogen peroxide signal produced by streptavidin or antibody was amplified by silver precipitation as follows: slides were sequentially incubated and washed at $22^{\circ} \mathrm{C}$ in $2.5 \mathrm{mmol} / 1 \mathrm{NaAuCl}$ pH 2.3 for five minutes; water for five minutes; and $0 \cdot 1 \mathrm{~mol} / \mathrm{l}$ sodium sulphide (adjusted to $\mathrm{pH} 7.5$ with 1 mol/l hydrochloric acid) for five minutes, and washed in water for five minutes. Silver was then precipitated at the sites of the hybridisation probe by incubating the cells at $22^{\circ} \mathrm{C}$ for two to six minutes in silver reagent; the final concentration of the constituents of this reagent are $0.24 \mathrm{~mol} / \mathrm{l}$ sodium carbonate (solution A), $0013 \mathrm{~mol} / \mathrm{l}$ ammonium nitrate (solution B1), $6.0 \mathrm{mmol} / \mathrm{l}$ silver nitrate (solution B2), $1.5 \mathrm{mmol} / \mathrm{l}$ dodecatungstosilicic acid (solution B3), containing $0.6 \mu \mathrm{l} / \mathrm{ml}$ of $40 \%$ (v/v) formal- dehyde (solution B4).

In practice, stock solutions were made up separately at twice the final concentration of solution $A$ and eight times the concentrations of solutions B1-3, stored at $4^{\circ} \mathrm{C}$, and warmed to $22^{\circ} \mathrm{C}$ before use. Complete solution $\mathrm{B}$ was first made up by adding, in numerical order (with vortexing), $1 \mathrm{ml}$ of solutions B1, B2, and B3 to a plastic tube containing $1 \mathrm{ml}$ of distilled water; $5 \mu \mathrm{l}$ of B4 was then added. One volume of complete solution B was added slowly to one volume of solution $A$ with vigorous vortexing. This complete reagent is stable at $22^{\circ} \mathrm{C}$ in ordinary daylight for at least $\mathbf{3 0}$ minutes. The stock solutions are stable at $4^{\circ} \mathrm{C}$ for at least one week.

In principle, this amplification procedure is based on the ability of DAB complexes to bind gold salts ${ }^{9}$ which, when converted to gold sulphide, precipitate metallic silver. ${ }^{10}$ The light insensitive silver reagent described here is a modification of one described earlier for detection of antibody. ${ }^{11}$ The reagent as previously described " is unstable and unsuitable for in situ detection of biotinylated probes.

After silver amplification the slides were washed at $22^{\circ} \mathrm{C}$ in distilled water for 15 minutes and 0.17 mol/l acetic acid (twice) for 15 minutes and stained with $1 \%(\mathrm{v} / \mathrm{v})$ pyronin in water for 30 seconds, or with haematoxylin and eosin. The slides were dehydrated in hot air (pyronin preparations only) or ethanol, washed in xylene, and mounted in DPX. For chromosomal assignment of pHY $2 \cdot 1$ chromosome spreads were banded as follows. Cells labelled with deoxybromouridine were stained for 15 minutes in Hoechst $33258(5 \mu \mathrm{g} / \mathrm{ml})$ dissolved in $2 \times$ SSC. Slides were rinsed and temporarily mounted in $2 \times$ SSC under cover slips, using a rubber sealing solution. The cells were irradiated with long wavelength ultraviolet light for one hour and counterstained with 7\% (Harleco, USA) Giemsa stain for 15 minutes, rinsed in distilled water, air dried, and mounted in Hystomount. All of these preparations are permanent and can be stored at room temperature.

\section{Results}

In fresh cultured lymphocytes probed with biotinylated $\mathrm{pHY} 2 \cdot 1$, using polyclonal goat antibiotin as the primary detection reagent, interphase white blood cells from phenotypically and karyotypically normal men showed a single, roughly circular black body (Fig. 1). This Y body represents the distal part of the long arm of the $Y$ chromosome. The $Y$ chromosome in interphase cells sometimes looks like two closely aligned structures (Figs. 8 and 9), which represent the two chromatids of the $Y$ chromosome. The $\mathrm{Y}$ chromosome usually lies at or 
Fig 1 Male cultured white blood cells. $Y$ bodies are located near nuclear membrane.
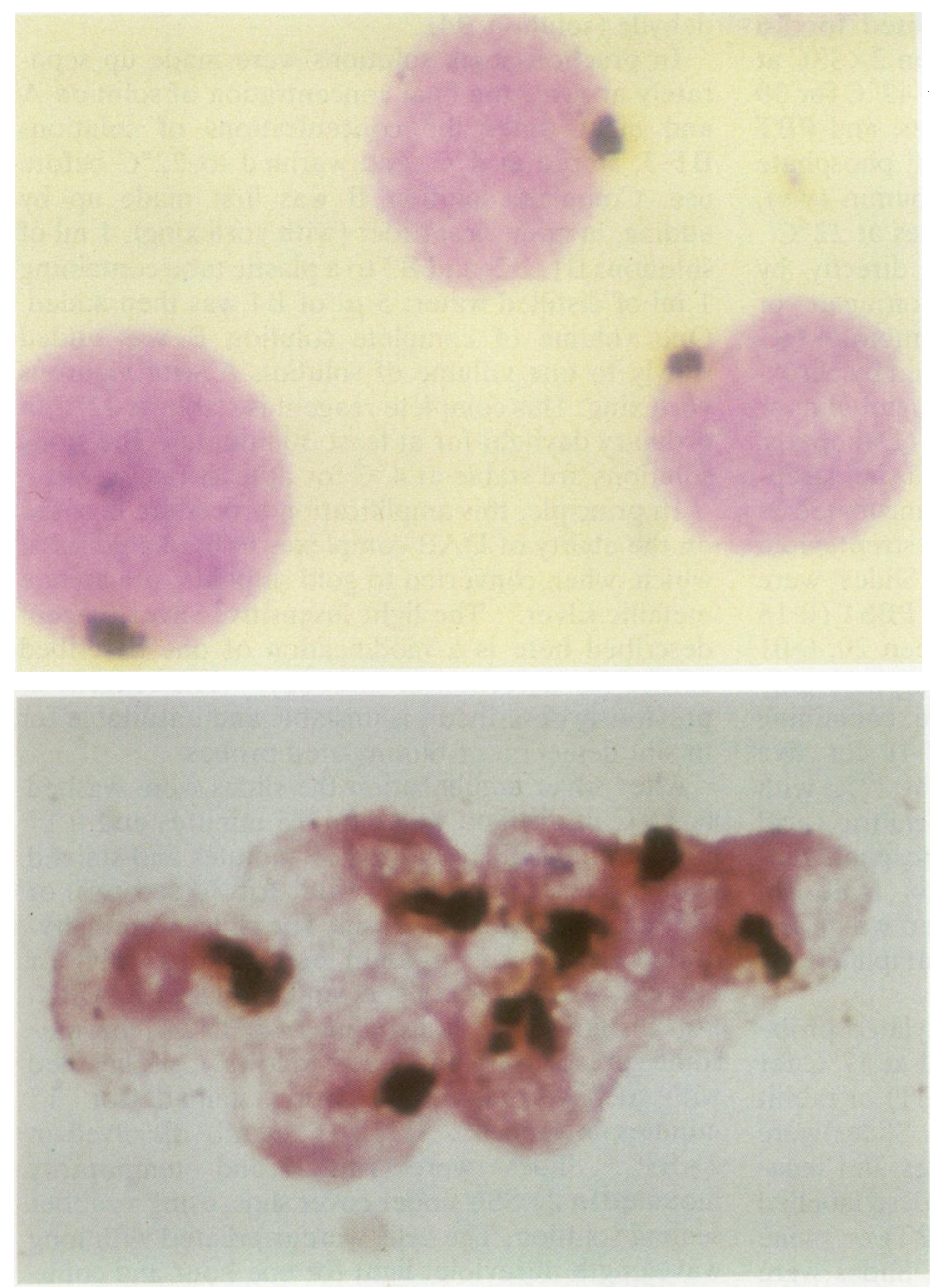

Fig 2 Male buccal smears. $Y$ bodies are evident in all basal cells.

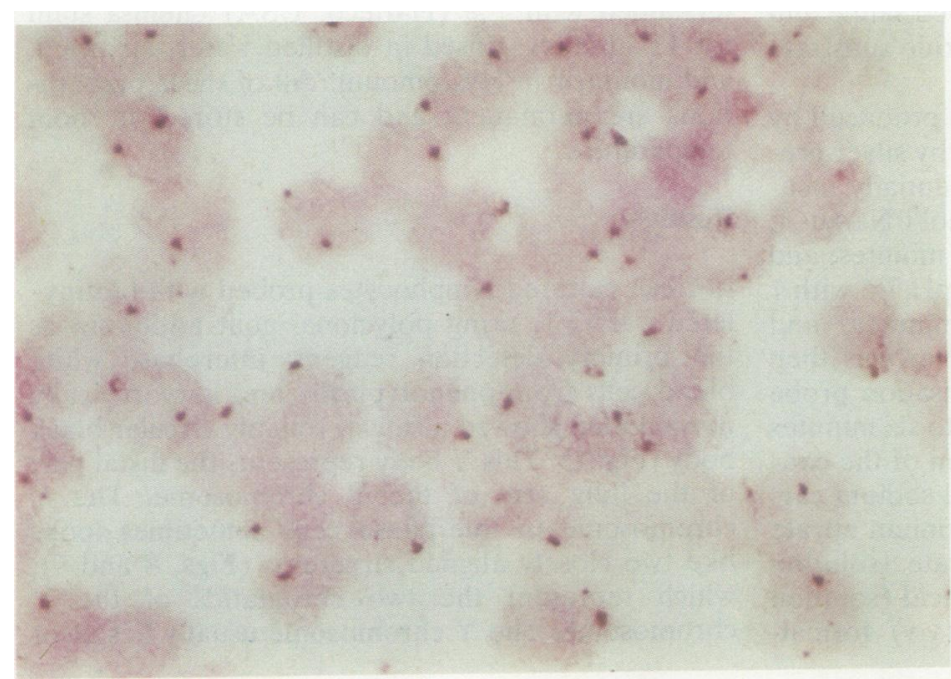

Fig 3 Fresh male lymphocytes

(cytospun). Every cell contains a Y body.

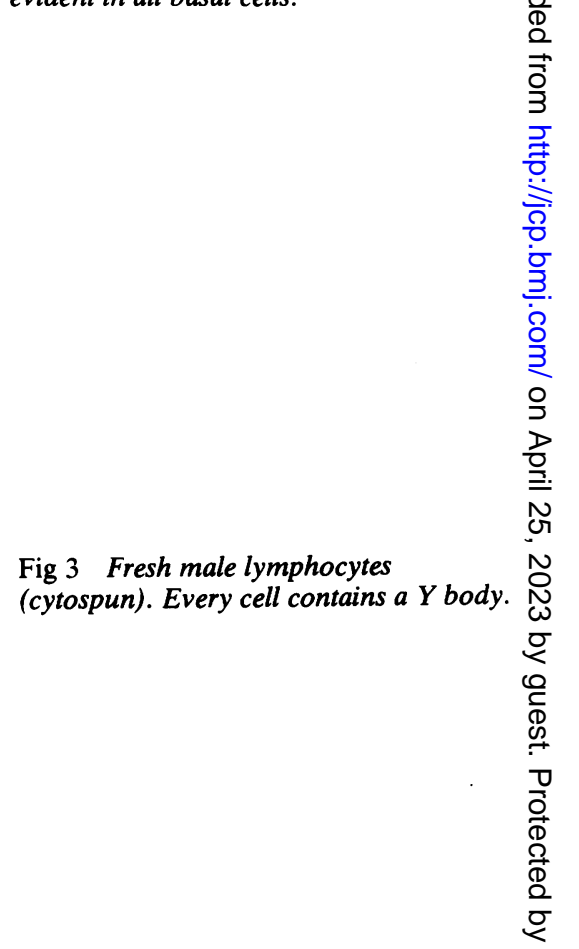




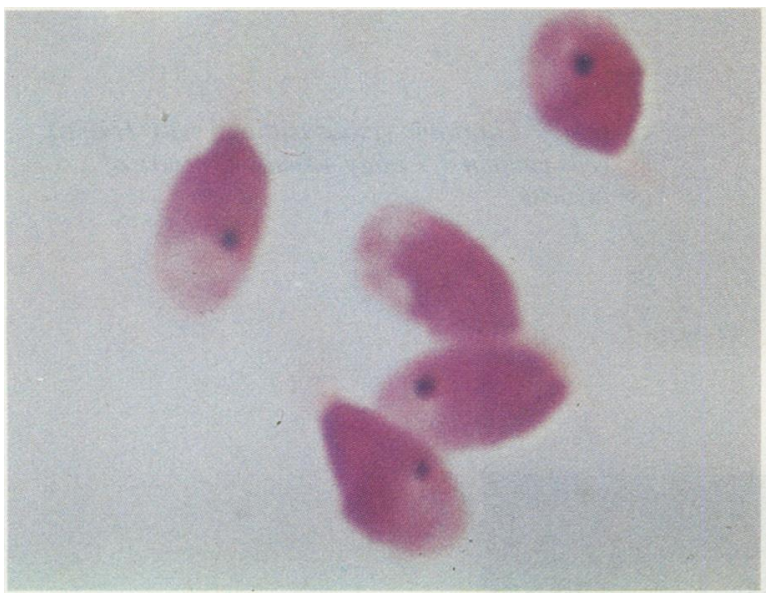

Fig 4 Human sperm. The $Y$ body is present in apical aspect of four out of five sperms.

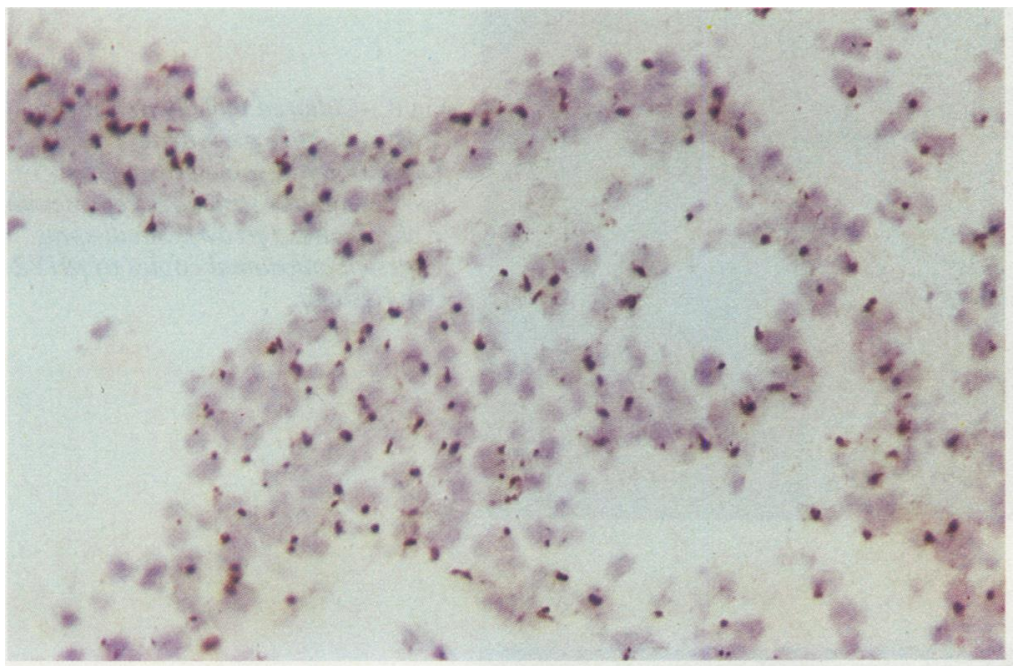

Fig 5 Normal human male lung. Almost all alveolar cells contain $Y$ body at membrane or centre of nucleus.

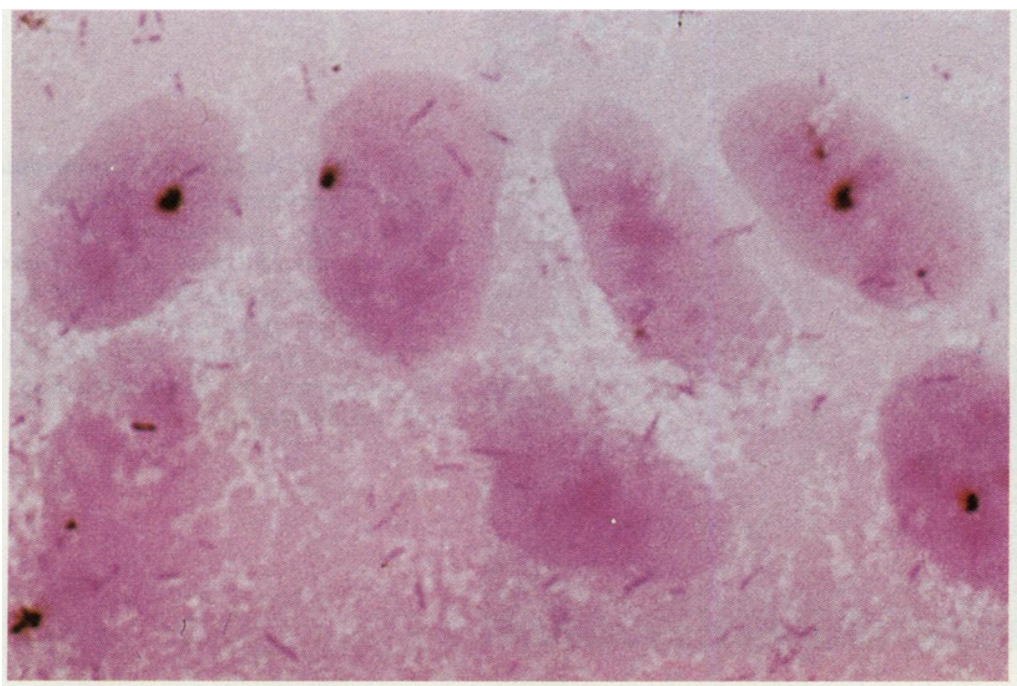

Fig 6 Cultured amniotic cells. Half of all cells show a Y body. The proteinaceous culture medium between cells is pyronin positive. 


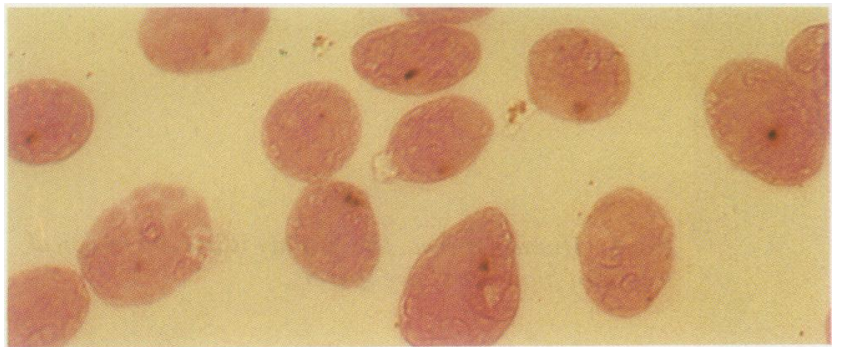

Fig 7 Chorionic villous cultured cells. Half of cells contain a $Y$ body, usually at centre of nucleus.

Fig 8 Cultured male lymphocytes. Most cells have peripheral $Y$ body. The $Y$ body in some cells consists of two contiguous structures representing $Y$ chromatids (arrow). Small spots represent autosomal copies of $\mathrm{pHY} 2$ (see Results).

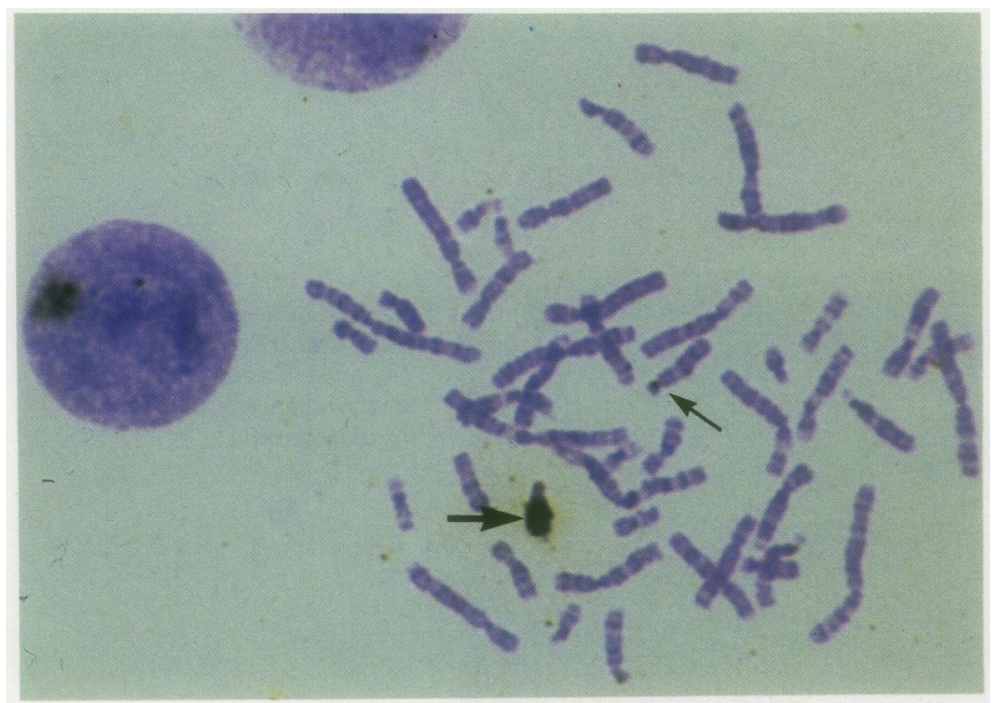

Fig 9 Male lymphocyte chromosome $\mathrm{O}$ spread. Y chromatids are labelled (large arrow), as is telomere of chromosome 15 (small arrow). There are a few grains on other autosomes. $N$ Full analysis of autosomal binding of pHY2.1 is in progress. Note that these chromosomes were Giemsa banded after probe detection. 
near the nuclear membrane of white blood cells. In cultured male white blood cells $60-96 \%$ had a Y body. Y bodies are not detectable in normal women. White blood cells probed with pBR322, or incubated with hybridisation buffer only, show no reaction.

In a double blind study we probed cultured lymphocytes from 20 karyotypically normal men and 20 women. In all 40 cases there was complete concordance between the presence of $\mathrm{Y}$ bodies in interphase cells and karyotypic sex. The preparations used in this experiment were up to one year old and had been stored at room temperature. The percentage of interphase cells containing $Y$ bodies, however, was about $60 \%$.

Buccal smears and fresh cytospun peripheral white blood cells from normal adult men and women were probed with biotinylated $\mathrm{pHY} 2 \cdot 1$; these preparations are ready for in situ hybridisation within one hour. In men all basal epithelial cells from buccal smears had a Y body (Fig. 2). Superficial squamous cells were $Y$ negative; one possible explanation for this is that probes penetrate poorly into partially keratinised cells. All male white blood cells separated from whole blood contained a Y body (Fig. 3). Female cells from buccal mucosa and peripheral lymphocytes did not contain a Y body.

Sperm taken from five normal, fertile men were probed with $\mathrm{pHY} \cdot 1$. Y bodies were visualised in sperms from all of them (Fig. 4). The percentage of $\mathrm{Y}$ positive cells varied in this small series from $35 \%-66 \%$. The Y spot was most commonly found in the upper half of the sperm head. Sperm count and motility in these cases were normal.

Almost all nucleated cells in frozen sections of tissues from adult men (lung, lymph node, gut, connective tissue) contained a Y body (Fig. 5), unlike cells from the tissue of women (breast, lung, lymph node, and colon). In interphase cells in solid tissue the $\mathrm{Y}$ chromosome was either at the nuclear membrane or in the centre of the nucleus (Fig. 5).

In a double blind study of free amniotic cells, amniotic cell cultures, and chorionic villi there was complete concordance between the presence of $Y$ bodies in interphase cells and karyotypic analysis. In free amniotic cells and cultures from male fetuses about $50 \%$ of cells were Y positive (Fig. 6). In organ cultures of chorionic villi usually only the cells growing out from the villi contained a detectable $Y$ body (Fig. 7). All of these preparations had been stored at room temperature for up to six months, which may explain the low incidence of positive cells.

These results were derived from cells probed with $0 \cdot 2-0 \cdot 5 \mathrm{ng}$ pHY2.1/10 ml hybridisation buffer and silver amplification for two minutes. When the probe concentration, its specific activity or silver amplification time are increased several small black spots can be visualised in normal male cells, in addition to Y bodies (Fig. 8); these small spots probably represent the autosomal copies of this gene. Under the same conditions similar small spots can be visualised in normal female interphase cells; female cells contain about 100 copies of this gene. ${ }^{7}$ These small spots are easily distinguished from $\mathrm{Y}$ bodies and were initially detected in cultured white blood cells that had been stimulated with phytohaemoglutinin. Chromosome spreads from fresh cultured lymphocytes were examined, therefore, to determine whether these optimal conditions could be used to assign pHY2. 1 to specific chromosomes. This probe labelled the tips of both chromatids of the long arm of the Y chromosome (Fig. 9). Every chromosome spread containing a $\mathrm{Y}$ chromosome was labelled in this way. The short arm of only one chromosome 15 is labelled in this subject (Fig. 9). The absence of labelling of the homologue of chromosome 15 is due to polymorphic variation in this particular individual. These chromosomes were Giemsa banded after in situ hybridisation; the quality of banding was as good as that obtained in regular cytogenetic practice.

We preferred polyclonal antibiotin (as the primary reagent) in the detection system rather than streptavidin because of its apparent higher sensitivity. Monoclonal antibodies to biotin, currently being tested (Burns and McGee, data not shown), give similar results to those shown in Figs. 1-9.

\section{Discussion}

With the detection procedure described, $\mathrm{pHY} 2 \cdot 1$ readily visualises the $Y$ chromosome in intact fetal and adult interphase and metaphase cells within 24 hours. When standard detection methods for biotinylated probes are used, the $\mathrm{Y}$ chromosome is visualised in interphase cells of adult solid tissue alone (data not shown). The number of male cells that are $Y$ positive in fresh white blood cells, white blood cell cultures, and solid tissues was $60-96 \%$ in the limited population sample studied. This figure is considerably higher than that obtained by the fluorescence method of visualising $Y$ bodies. ${ }^{8}$ With the present method $Y$ bodies are visualised against a negative background; with fluorescence methods the $Y$ body is seen as a brighter spot in an otherwise less fluorescent background. Fluorescent preparations are not permanent, unlike those shown here. Fluorescence methods have been used rarely for analysis of $Y$ positive cells in tissue, probably because of non-specific background noise. It would be interesting to use the present method to sex cells in tumours of supposed germ cell origin. 
The results of the sperm analysis clearly distinguish Y positive sperms, allow for analysis of the incidence of disomic sperms, and also, perhaps, give useful information about infertile men. Complementary ribonucleic acid from $\mathrm{pHY} 2 \cdot 1$ did not successfully identify $\mathrm{Y}$ bodies in ejaculated sperm. ${ }^{12}$

Fetal sexing on chorionic villi can be performed in 24 hours with this in situ technique. This is more rapid than karyotypic analysis of cultured cells, which are usually not available for two to three weeks, or dot blot analysis. ${ }^{13} \mathrm{Y}$ bodies can also be visualised in 16 cell embryos generated by in vitro fertilisation (Burns and McGee, unpublished data). If individual blastomeres could be removed from early human embryos without compromising viability $^{14}$ (as in animals ${ }^{15}$ ) sex could theoretically be assessed before reimplantation. In vitro fertilisation would then assume therapeutic importance in areas other than infertility.

Clearly, silver amplification of the $\mathrm{DAB} /$ hydrogen peroxide signal can be used for the chromosomal assignment of genes present in high copy number; there are about 2000 copies of pHY2. 1 in the $\mathrm{Y}$ chromosome. Some autosomal copies of this gene (100-200 copies) can be clearly visualised, however, on chromosome 15 (Fig. 9). This implies that we can identify genes present in fewer than 100 copies. Recent studies indicate that single copy genes can also be assigned to specific chromosomes. ${ }^{16}$ Chromosomal assignment of genes by in situ hybridisation with radiolabelled probes requires autoradiographic exposure lasting weeks and is complicated by background noise. With the present procedure chromosomes are ready for analysis in one day.

The final reaction product of the silver amplification procedure for visualising biotinylated probes is metallic silver. This is electron dense and can be visualised by regular and back scatter scanning electron microscopy. ${ }^{17}$ The $\mathrm{Y}$ chromosome is easily visualised by this technique in interphase cells and chromosome spreads. ${ }^{16}$ We are presently attempting to locate the autosomal copies of pHY 2.1 by this method as it will resolve location of the chromosomal genes more accurately.

Preliminary evidence indicates that biotinylated probes detected by silver amplification visualise relatively small numbers of messenger ribonucleic acid transcripts of cellular oncogenes in sections of solid tumours. ${ }^{18}$

This work was supported by grants from the Cancer Research Campaign and the Medical Research Fund, University of Oxford. VTWC was in receipt of a T W Chang postgraduate scholarship and was also partially supported by the Cancer Research Campaign. Dr M Hulten, cytogenetics department,

Birmingham, provided the sperm preparations. We thank Dr H J Cooke, (Mammalian Genome Unit, Edinburgh) for supplying pHY2.1, Mr C R Patel and Dr M Crocker for technical help, and Mrs Vera Macintosh and Miss Lesley Watts for typing the manuscript.

\section{References}

' Weatherall DJ. DNA in medicine: implications for medical prac- है tice and human biology. Lancet 1984;ii: 1440-4.

${ }^{2}$ Weiss RA, Marshall CJ. DNA in medicine: oncogenes. Lancet 1984;ii: 1138-42.

${ }^{3}$ Langer PR, Waldrop AA, Ward DC. Enzymatic synthesis of biotin-labeled polynucleotides: novel nucleic acid affinity probes. Proc Natl Acad Sci USA 1981;78:6633-7.

${ }^{4}$ Manuelidis L, Langer-Safer PR, Ward DC. High-resolution $\omega$ mapping of satellite DNA using biotin-labeled DNA probes. Journal of Cell Biology 1982;95:619-25.

${ }^{5}$ Brigati DJ, Myerson D, Leary JJ, et al. Detection of viral genomes in cultured cells and paraffin-embedded tissue sec- $\bigcirc$ tions using biotin-labeled hybridization probes. Virology o

1983; 126:32-50.
- Leary JJ, Brigati DJ, Ward DC. Rapid and sensitive colorimetric method for visualizing biotin-labeled DNA probes hybridized to DNA or RNA immobilized on nitrocellulose: bio-blots. Proc Natl Acad Sci USA 1983;80:4045-9.

${ }^{7}$ Cooke HJ, Schmidtke J, Gosden JR. Characterisation of a human $\mathrm{Y}$ chromosome repeated sequence and related sequences in higher primates. Chromosoma 1982;87:491-502.

${ }^{8}$ Mittwoch U. Sex chromatin bodies. In: Yunis JJ, ed. Humøn chromosome methodology. Academic Press, New Yo 1974:73-91.

" Adams JC. Heavy metal intensification of DAB-based HF reaction product. $J$ Histochem Cytochem 1981;29:775.

${ }^{10}$ Timm F. Zur Histochemie der Schwermetalle; Das Sulfidsilberverfahren. Zeischrift Für Die Gesumte Gerichtliche Medi- ̊̊ zin (Berlin) 1958;46:706-11.

"Gallyas F, Gorcs T, Merchenthaler I. High-grade intensification of the end-product of the diaminobenzidine reaction for perox- 0 idase histochemistry. J Histochem Cytochem 1982;30:183-4. Э

12 Joseph AM, Gosden JR, Chandley AC. Estimation of aneuploidy levels in human spermatazoa using chromosome specific probes and in situ hybridisation. Hum Gene (Berlin) 1984;66:234-8.

${ }^{13}$ Yun-Fai L, Huang JC, Dozy AM, Wai Kan YA. A rapid screening test for antenatal sex determination. Lancet 1985;i:14-6.

14 Anonymous. Embryo research [Editorial]. Lancet 1985;i: 255-6.

is Willadsen SM. The development capacity of blastomeres from 4- and 8-cell sheep embryos. J Embryol Exp Morphol 0 1981; 65: 165-72.

${ }^{16}$ Burns J, Jonasson JA, Chan V, McGee JO' D. Gene localisation D by in situ hybridisation of biotinylated probes: chromosomal gene assignment. J Pathol 1985; 145:110(A).

17 Ferguson DJP, Harrison D, Burns J, Jonasson JA, Chan V, $\mathcal{N}$ McGee JO'D. Gene localisation by in situ hybridisation of biotinylated probes: localisation of a $Y$ specific marker to the $\bigcirc$ Y chromosome by scanning electron microscopy. J Pathol $\mathrm{W}$ 1985; 145:110(A).

18 Burns J, Taylor S, Chan V, Fleming KA, McGee JO'D. Gene/ mRNA localisation by in situ hybridisation of biotinylated probes: demonstration of the ras and c-myc genes in human $\mathbb{E}$ tumours. J Pathol 1985; 145:110(A).

Requests for reprints to: Professor JO' D McGee, Nuffield ${ }_{0}^{-}$ Department of Pathology, John Radcliffe Hospital, Oxford OX3 9DU, England. 